\title{
OBSERVATIONS IN A COLD ICE CAP*
}

\section{$B y$}

R. HAefeli (Versuchsanstalt für Wasserbau und Erdbau an der E.T.H., Zürich)

and

F. Brentani (Ingenieurbureau Rothpletz Lienhard \& Cie., Berne)

Abstract. In the approximately $50 \mathrm{~m}$. thick ice cap of the Jungfraujoch ( $3470 \mathrm{~m}$, above sea level), where the temperature throughout lies below the pressure melting point, continual measurements of displacement and deformation were carried out inside ice tunnels from I950 onwards. These give an insight into the process of movement, the formation of water-filled crevasses and the relationships of viscosity in a cold ice cap glacier.

The plastic behaviour of the cold ice was examined through alterations in length of individual tunnels, and also through measured distortions of cross-section in circular sections of tunnel. Since the mean ice temperature in the region of the ice tunnel lies approximately between $-I^{\circ}$ and $-3^{\circ} \mathrm{C}$., these examinations provide a welcome supplement to analogous measurements which were taken in circular tunnels in a temperate glacier (Z'Mutt tunnel). The approximate calculation of the plastic deformation of a circular tunnel was thus extended by the obvious transformation of solutions known from elasticity theory.

By means of a qualitative analysis of the state of stress of an ice cap, an attempt is made to account for the distortion and the formation of the cracks and crevasses which were observed. The occurrence of blue bands could be followed in statu nascendi. This paper serves as a primary orientation and publishes some initial results of the examinations which are to be continued and completed over a number of years. In addition to its potentialities for examinations which are to be continued and completed over a number of years. In addition to its potentialities for practical use, this study may be of interest in respect to the behaviour of cold glaciers of the Arctic and Antarctic.
In a final section, therefore, some problems of the Greenland ice sheet are considered in the light of the preceding conclusions.

Zusammenfassung. In der ca. $50 \mathrm{~m}$. mächtigen Eiscalotte des Jungfraujoches ( $3470 \mathrm{~m}$.ü.M.), deren Temperatur durchgehende unter dem Druckschmelzpunkt liegt, wurden seit 1950 im Innern von Eisstollen kontinuierlich Verschiebungs- und Deformationsmessungen ausgeführt, die einen Einblick in den Bewegungsvorgang, die Bildung von wassergefüllten Spalten, sowie die Zähigkeitsverhältnisse eines kalten Kalottengletschers gestatten.

Das plastische Verhalten des kalten Eises wurde einerseits auf Grund der Längenänderung einzelner Stollen und anderseits auf Grund der gemessenen Querschnittsverformungen kreisförmiger Stollenabschnitte untersucht. $\mathrm{Da}$ die mittlere Eistemperatur in der Umgebung der Eisstollen ca. zwischen $-\mathrm{I}^{\circ}$ und $-3^{\circ} \mathrm{C}$. liegt, bilden diese Untersuchungen eine willkommene Ergänzung analoger Messungen, die an Kreisstollen eines temperierten Gletschers ausgeführt Kreisstollens wurde dabei durch die sinngemässige Übertragung der aus der Elastizitätslehre bekannten Lösungen Kreisstol

Auf Grund einer qualitativen Analyse des Spannungszustandes der Eiskalotte wird versucht, die beobachteten Auf Grund einer qualitativen Analyse des Spannungszustandes der Eiskalotte wird versucht, die beobachteten
Verformungen, Riss- und Spaltenbildungen des Eises zu erklären. Die Entstehung von Blaubändern konnte im status nascendi verfolgt werden. Die vorliegende Mitteilung dient als erste Orientierung und gibt einige vorläufige Resultate der während mehrerer Jahre fortzusetzenden und zu ergänzenden Untersuchungen bekannt. Abgesehen von ihren praktischen Anwendungsmöglichkeiten, dürfte diese Studie im Hinblick auf das Verhalten kalter Gletsche der Arktis und Antarktis von Interesse sein. In einem letzten Abschnitt werden deshalb einige Probleme des grönlandischen Inlandeises im Lichte der vorliegenden Ergebnisse diskutiert.

\section{CON T E N T S}

Section I. Introduction.

PART I

, II. Morphological Relationships.

" III. Measurements of Movement and Deformation.

PART II

Section IV. Relationships of Stress and Temperature.

" V. Viscosity Relationships in Cold Ice.

" VI. Comparison of Greenland and Alpine Relationships.

Sections IV, V and VI will appear in the next issue of the Fournal.

\section{INTRODUCTION}

The behaviour of an ice cap is of particular interest in relation to Arctic and Antarctic glaciological problems, especially in connection with investigation of the Greenland ice sheet. A favourable opportunity to set about an examination of the stress, movement and temperature relationships

* Amplified version of a paper read in French at the tenth General Assembly of the I.U.G.G., Rome, 1954. 
in a cold ice cap presented itself in $195^{\circ}$ when for constructional purposes the $50 \mathrm{~m}$. deep ice cap of the Jungfraujoch ( $347^{\circ} \mathrm{m}$. above sea level) had to be traversed by a $130 \mathrm{~m}$. ice tunnel (Fig. I, p. $5^{81}$ ).

Since this tunnel would have to be maintained for at least ten years and sensitive installations housed therein, a system of observation tunnels was constructed for reasons of safety and control: these serve above all for the examination of ice movement and of creep in the cold ice.

On the basis of measurements of plastic distortion in ice tunnels of circular cross-section the state of stress and the relationships of plasticity were checked against theoretical calculations. A small ice laboratory served for carrying out loading tests of long duration on the ice in situ. The location of the top layer of rock was successfully established with the aid of hot water borings.

Within the narrow frame of the present paper it is not possible to give a detailed account of the execution and of the results of the research since it was commenced in $195^{\circ}$. Our article is primarily intended to make known the most important results of the last four years, together with an initial orientation of a general nature. The comparison ${ }^{1}$ with earlier research of a similar type in temperate glaciers makes possible a brief survey of the plastic behaviour of cold and temperate ice. Finally, some links with the exploration of the Greenland ice sheet are examined, with particular reference to the results of Expéditions Polaires Françaises of Paul-Émile Victor (I948-5I).2, 3, 4

\section{Morphological Relationships}

The deepest rock depression in the Jungfraujoch has the shape of a saddle, covered by a flat cap of firn and ice, which lies within the permafrost zone. While the southern part of this cap passes over into the Jungfrau firn of the Great Aletsch Glacier and is only separated from it by the bergschrund, towards the north it drops gently down for a distance of about $200 \mathrm{~m}$. as far as the edge of the so-called Plateau, where the tumbling blocks of ice plunge down the steep northern face of the Bernese Alps towards the Guggi Glacier. To the east of the deepest part of the saddle rises the peak of the Sphynx, to the west, the sharp Mathilde ridge, which continues into the east ridge of the Jungfrau. Fig. I shows the cap from the north side of the Bernese Alps looking towards the Aletsch Glacier, and Fig. 2 (p. 573) the topography of the firn surface, together with the position of the ice tunnels. In Fig. 3, (p. 575) the most important cross profiles are represented, and for Profile $\mathrm{hm}$. I.00, the outline of the bedrock in the neighbourhood of the saddle is also given, as ascertained by a series of hot-water borings.

As can be seen from the diagrams, a succession of typical longitudinal crevasses were encountered when the tunnels were being dug: as a rule, these extend neither to the surface of the firn, nor to the rock base, but are sealed interglacially both above and below. The biggest of these crevasses was struck on 8 October I $95^{\circ}$ at $\mathrm{hm} .0 .85$ by the main or longitudinal tunnel, which was climbing westwards at a gradient of about 12 per cent towards the Mathilde. Since this crevasse SI was filled with water to a level about $1 \cdot 5 \mathrm{~m}$. above the ceiling of the tunnel, a dangerous outburst of water followed. This poured out on to the Jungfrau firn through a gallery, F2, set at the lowest point in the tunnel : in parts, the tunnel was filled to the ceiling with water. The crevasse was about $50 \mathrm{~m}$. long and at its widest $10 \mathrm{~m}$. across, and its deepest point lay about $33 \mathrm{~m}$. below the firn surface: it was bridged by a solid covered-in wooden gallery, and when work recommenced, borings were carefully made so as to avoid an unexpected outburst of water.

The shape and position of the crevasse SI can be seen in longitudinal section or plan in Fig. 2 and in separate cross-sections in Fig. 4 (p. 575). From the lamella-shaped deposits of ice, observed at various levels, it is quite clear that in earlier times the crack was filled with water as far up as reference line $345^{\circ}$. Excluding the southern bergschrund (B), three other longitudinal cracks were encountered during the making of the two cross-tunnels $Q_{100}$ and $Q_{120}$ : their form can be seen in figures 3,6 and 7 . All these cracks were filled with water above the height of the tunnel and had to be drained off. The smallest, only $16 \mathrm{cms}$. wide, was struck during the construction of the crosstunnel $\mathrm{Q}_{120}$ at $03.00 \mathrm{hr}$. on $8 / 2 / 53$, at a distance of $\mathrm{I} 3.4 \mathrm{~m}$. from the main tunnel, whereupon there appeared at the breast of the tunnel a hole about $10 \mathrm{cms}$. across, through which water at 

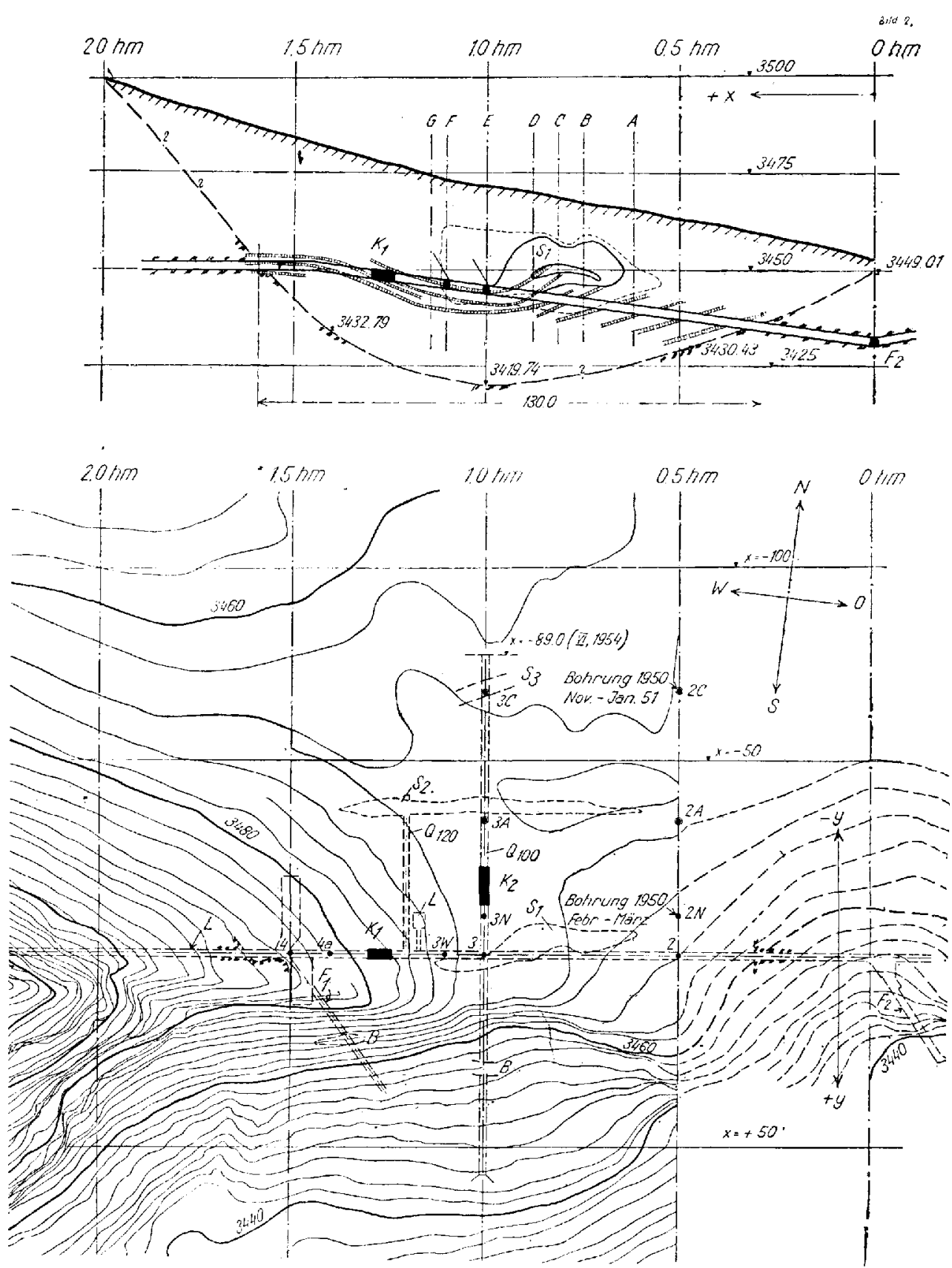

Fig. 3 (above). Longitudinal profile of the Ice Cap at the position of the principle tunnel.

(below). Plan of the Ice Cap showing the location of the longitudinal tunnel (L) (principal tunnel), and the cross-tunnels $Q_{100}$ and $Q_{120} . F_{1}$ and $F_{2}$ are window tunnels, $S$ are longitudinal crevasses, $B$ is the southern

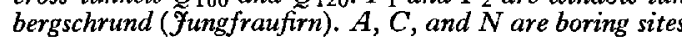


$0^{\circ} \mathrm{C}$. poured out at a rate of 5 or 6 litres a minute. At I5.I $5 \mathrm{hr}$, after a sharp report, the strong noise resulted in an increased flow of water. The air temperature in the tunnel was $-3^{\circ} \mathrm{C}$, , outside it was about $-30^{\circ} \mathrm{C}$. and the ice temperature in the cross-tunnel was estimated at $-2^{\circ}$ or $-3^{\circ} \mathrm{C}$.

From November 1953 until June 1954 the cross-tunnel $Q_{100}$, illustrated in Figs. 3 and 7 (p. 577), was excavated as an observation tunnel, during which the following longitudinal crevasses were encountered : about 26 metres south of the main tunnel, the bergschrund $B$, whose wall on the valley side was displaced almost vertically downwards at the rate of about $\mathrm{I}$ m. per month. Approximately $40 \mathrm{~m}$. north of the main tunnel, the longitudinal crevasse $\mathrm{S} 2$ was traversed, which yielded 8-10,000 cu. m. of water, and which communicated with that crack, whose existence had been established around $70 \mathrm{~m}$. north of the main tunnel. Between these two longitudinal cracks, two smaller cracks were also encountered.

The origin of the longitudinal cracks is explained by the relationships of stress and deformation while their filling up with water is conditioned thermodynamically. (Compare Sections III and IV.) Structurally interesting is the run of primary banding, which has arisen through metamorphosis from the firn banding, and in which the morphology of the rock base is so clearly shown that after some practice, the inclination of the rock foundation can be deduced approximately from the direction of the banding. So it may be concluded from the measurements of banding in the cross-tunnel $\mathrm{Q}_{100}$, that the saddle point (culmination) of the bedrock, lying some $20 \mathrm{~m}$. deeper, should be situated $3 \circ$ to $40 \mathrm{~m}$. north of the main tunnel; this was in fact confirmed by borings made in this profile. The neighbouring cross-tunnel $\mathrm{Q}_{120}$ also produced a similar picture (Figs. 6 and 7, p. 577).

That disturbances in the course of the bands must occur in the immediate proximity of cracks is obvious. The correspondence between banding and the rock surface was particularly clear where the tunnel passed from the rock into the ice at $\mathrm{hm} .0 .3^{\circ}$; that is to say, in a pronounced pressure zone. At the junction, the clear ice is frozen hard to the clean rock surface. Since, under these conditions, no slipping of the cold ice takes place on the rock, the longitudinal cracks observed never reach down to the rock bed, as has already been mentioned, and so the completely watertight cracks fill up with melting-water from above, even with a relatively small inflow during the hot season. Much less securely fixed is the junction between ice and rock at the western upper end of the ice tunnel, which lies in an area of tension (hm. I.6). The correspondence between ice banding and rock surface is not present here.

In striking contrast to the primary band structure are the blue bands, which can here be observed in statu nascendi. It repeatedly happened that in the cross-tunnels and the ice laboratory, fine cracks opened up under a sharp blow: these gradually widened, to change into a small blue band after the water, which had percolated down from the melting glacier surface, had frozen again. As a rule, the blue bands cut the primary banding at an obtuse angle or else they are perpendicular to it ( $c f$. Figs. 6 and 7 ). Especially instructive in this respect is the course of blue bands in the $130 \mathrm{~m}$. long cross-tunnel $\mathrm{Q}_{100}$, in the middle of which occurs a more horizontally positioned lenticular blue band. Its particular form can be explained as follows :

Imagine that where the movement of the cap divides (i.e. at the boundary between movement in northerly and southerly directions), at a point where, by definition, only vertical movement can take place, there arises a vertical fissure under the influence of horizontal tensile stresses. After filling with water and under the influence of hydrostatic pressure this fissure gradually assumes the typical shape, which is schematically indicated at the right hand side of Fig. 3 . The blue band caused by the freezing of the water-filled crevasse will be deformed according to the laws of creep movement and in the course of time take on the shape indicated by the stages of development " $a$," "b" and " $c$ ": that is to say, it will be drawn out horizontally in the two opposite directions of movement (north and south). Measurement now showed that at the present time the division of movement in the cross-tunnel $Q_{100}$ lies between the longitudinal tunnel and crevasse $\mathrm{S} 2$. In fact, a horizontally extended blue band of the form theoretically to be expected was discovered and sketched in this zone by an observer who had no knowledge of these kinematic relationships. 


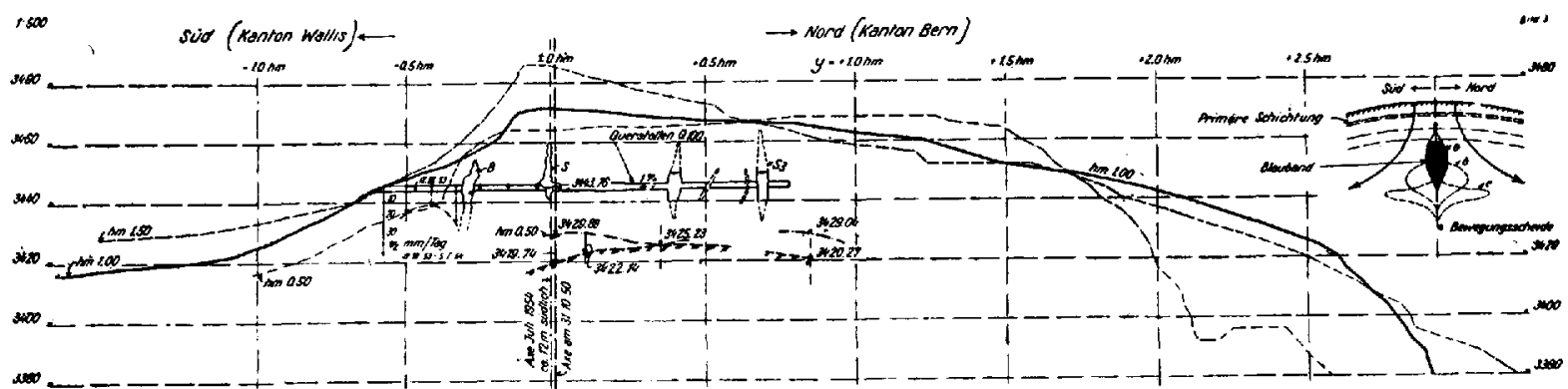

Fig. 3. Cross-sections through the Ice Cap at three locations shown in Fig. 2 (p. 573), together with diagram (top right) to illustrate the formation of the central blue band at the division of movement

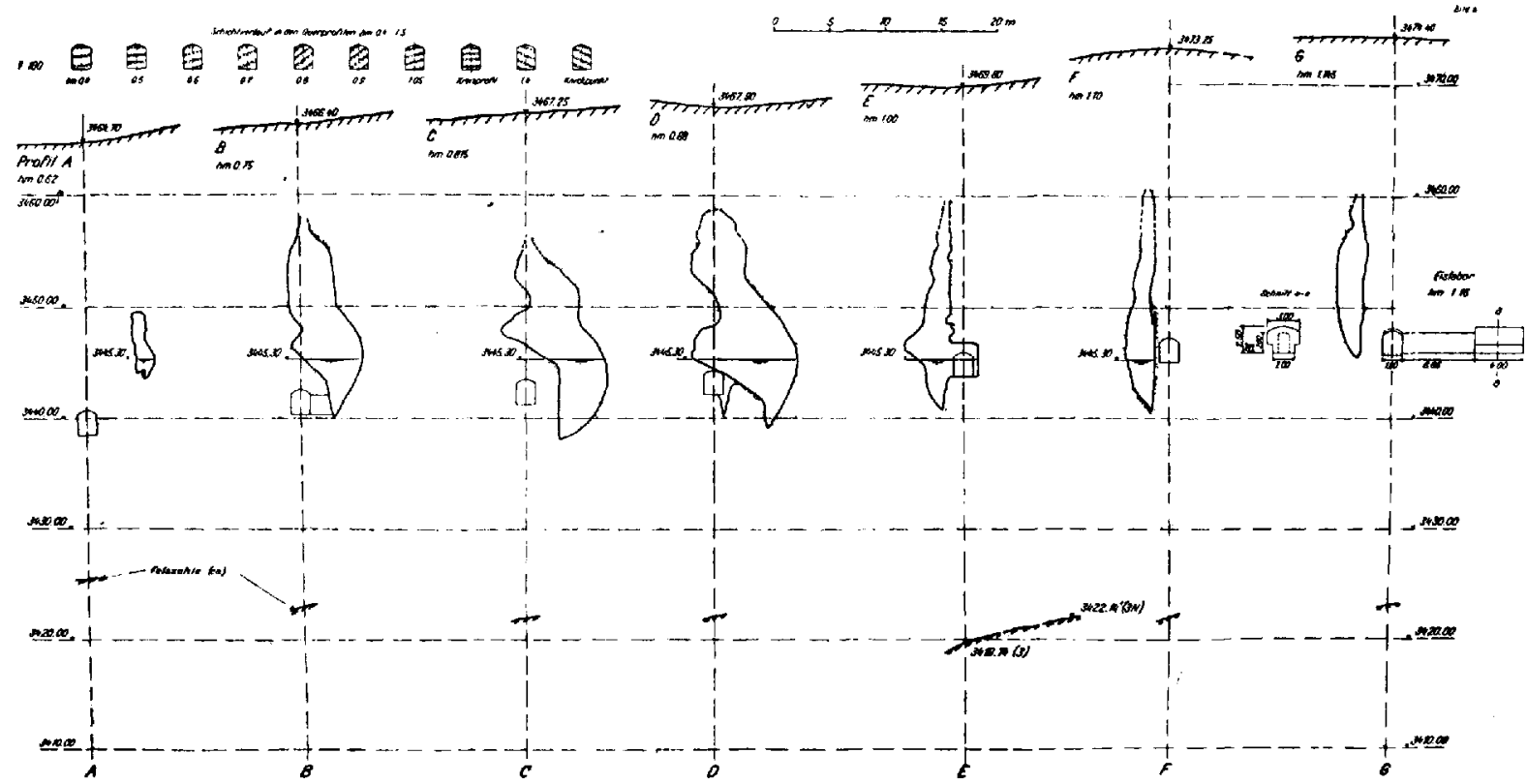

Fig. 4. Various profiles of Longitudinal Crevasses $S_{1}$ (c.f. Fig. 2)
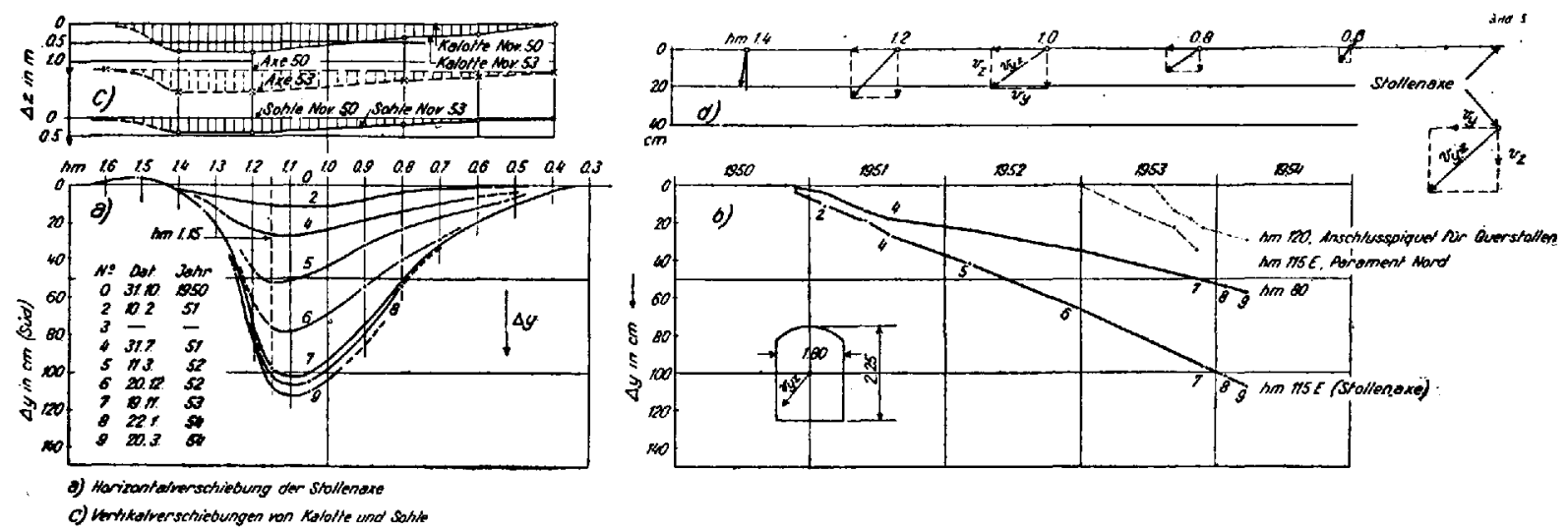

Fig 5. (a) Horizontal movement ( $4 y$ ) of the axis of the longitudinal tunnel at various dates. (b) Graph of $\Delta y$ as a function of time. $(c)$ Vertical movement $\Delta z$ of roof and floor of the tunnel and hence of its axis. (d) Vectors showing the movement of the tunnel axis at various points along its length 
(Fig. 7 , middle.) In contrast to the bubble-filled and rather finely crystalline ice between the blue bands, the blue band itself consists predominantly of very coarse-grained ice, as clear as pure water. The magnitude of the crystals in different zones was estimated, the average size being between 5 and $12 \mathrm{~cm}$. long. This unusual size of crystal may be due primarily to the slow process of freezing. Crystallographic examinations are planned by Professor A. Renaud. Fig. Io (p. 581) is a photograph of a finer-grained blue band, the structure being shown up by hoar which had formed upon it.

\section{iII. Measurements of Movement and Deformation}

Considered from a purely practical point of view, the overall arrangement of the network of observations and the position of the observation-tunnels were so contrived that in the course of time, the spatial movement in the interior and on the surface of the ice cap could be assessed, so as to arrive at the true velocity vectors in magnitude and direction, and to establish their periodic variation. Up to the present, however, this aim could be only partially achieved, for the surface measurements are not yet sufficiently far advanced. The following results are therefore concerned almost exclusively with the measurements carried out during the period $195^{\circ}-54$ in the interior of the system of tunnels. 5,6

\section{Longitudinal Tunnel (East-West)}

Fig. 5a (p. 575) illustrates first the horizontal components $\Delta y$ of the southerly displacement of the tunnel axis, i.e. the bending of the once straight axis at different dates $(2-9)$ during the period of construction, 1950-54. From this, there arises on the one hand the immobility of the two ends of the tunnel, which are frozen hard onto the rock, and on the other hand, the strong local increase in movement in the region of crevasse I (the zone of north-south tension). The greatest horizontal velocity was found to be at point $\mathrm{hm}$. $\mathbf{I} \cdot \mathbf{r}$, with about $33 \mathrm{~cm}$. a year. In Fig. $5^{b}$, the variation with time of the southerly displacement at single points is shown, from which can be seen a notable steadiness of the average speed of movement. The measurements during the years $195^{\circ-52}$ reveal but indistinctly a certain yearly rhythm of velocity in the form of a slowing-up in winter. Fig. $5 c$ shows the vertical movements $\Delta z$ of the roof and base of the tunnel; these, however, are shown on a scale ten times smaller than that of the horizontal displacements $\Delta y$. The true direction and magnitude of the displacement of the tunnel-axis in the vertical plane $y z$ is represented in Fig. $5 d$ by the mean annual velocity during the period $195^{\circ}-53$ for different points in the longitudinal tunnel. From this it follows, as was to be expected, that these vectors are steeper than the rock surface ( $c f$. Fig. 3 ). The third component of movement in the $x$-direction is established with the aid of longitudinal measurements in the tunnel L. In the main, only qualitative results can be obtained about it. The slope of the firn surface in longitudinal section, clearly discernable in Fig. 2, in conjunction with the course of the rock-contour, brings about a displacement to the east between the two ends of the tunnel which are firmly anchored to the rock : this reveals a zone of tension at $\mathrm{hm} . \mathrm{I} \cdot 5$ and a zone of compression at $\mathrm{hm} .0 .5$.

With regard to the deformation of the tunnel cross-sections, which were measured at regular intervals of time, the following general picture was built up: Whereas the width of the tunnel remained nearly unchanged, the clear height diminished during three years from 2.5 to $2.15 \mathrm{~m}$., i.e. about $12 \mathrm{cms}$. a year, while the thickness of ice above amounted to roughly $30 \mathrm{~m}$. $(\mathrm{hm}$. $1 \cdot 2-$ r 4). Accordingly (as in Fig. $5 d$ ) the vertical displacement of the top was I2 cm. greater than that of the bottom, at most about $25 \mathrm{~cm}$. as opposed to $13 \mathrm{~cm}$. per year. The vertical displacement of the tunnel axis was taken as the average of these two displacements.

In order to arrive more accurately at the state of stress from the deformations of the crosssection, an extension of the tunnel, $6 \mathrm{~m}$. long and of circular cross-section, $2.9 \mathrm{~m}$. in diameter, was cut out at hm. $\mathrm{r} \cdot 3^{\circ}$, i.e. at a point where the covering ice was about $3 \circ$ m. thick. Fig. 8 (p. 579) shows the deformations of the circular profile observed during the course of two years. While the horizontal diameter of the profile remained almost unchanged, the vertical diameter underwent 


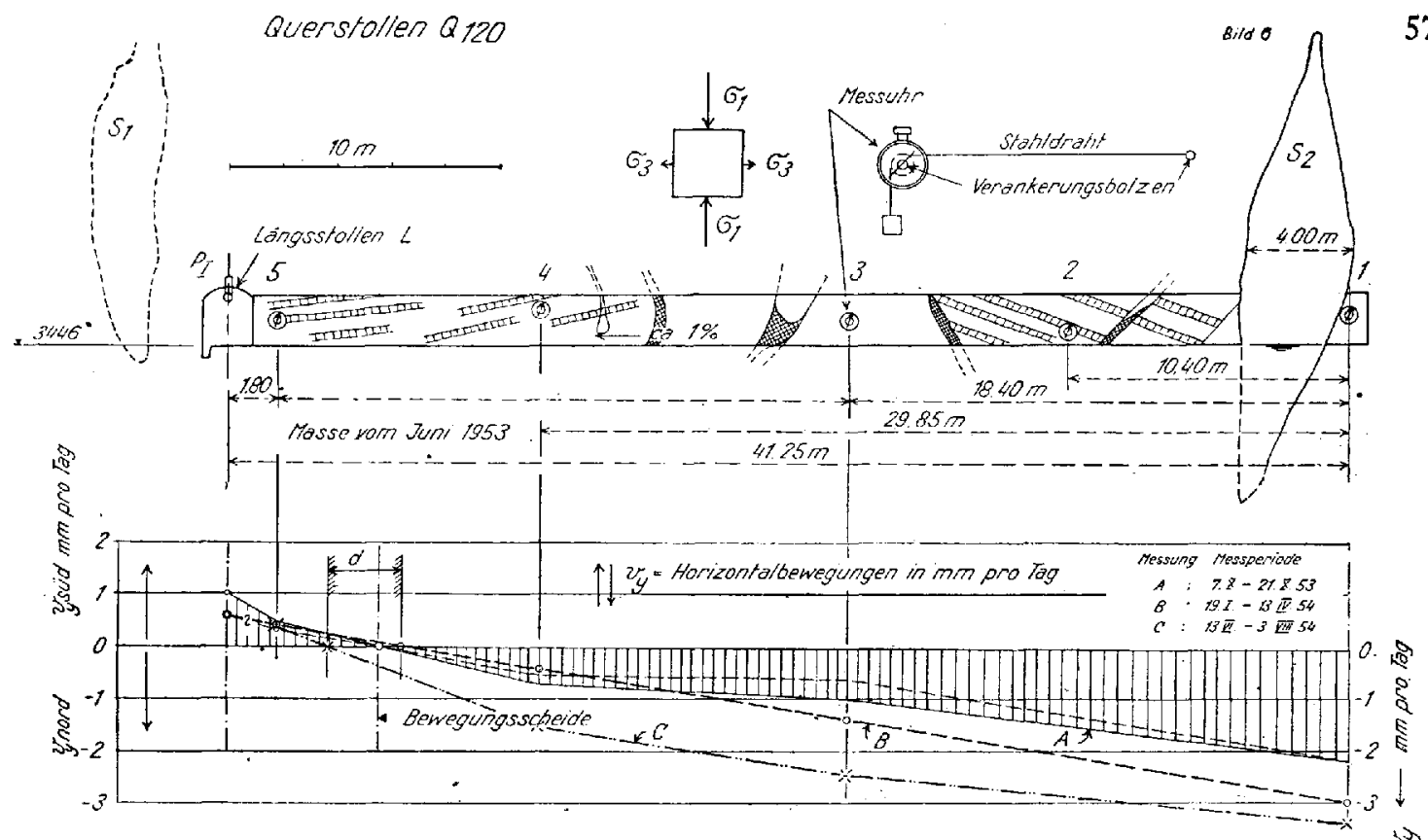

Fig. 6 (above). Profile of Cross Tunnel $Q_{120}$ showing the layering and blue band structure, also the method of measuring longitudinal extension. (Messuhr=dial gauge, Stahldraht =steel wire, Verankerungsbolzen= anchoring bolts.) (below). Horizontal displacements $\left(v_{y}\right)$ in $\mathrm{mm}$. per day over three measuring periods. (Bewegungsscheide= division of movement.)

\section{Querstollen Q100 (Ausführung Nov. 1953 - Juni 1954)}

aid ?
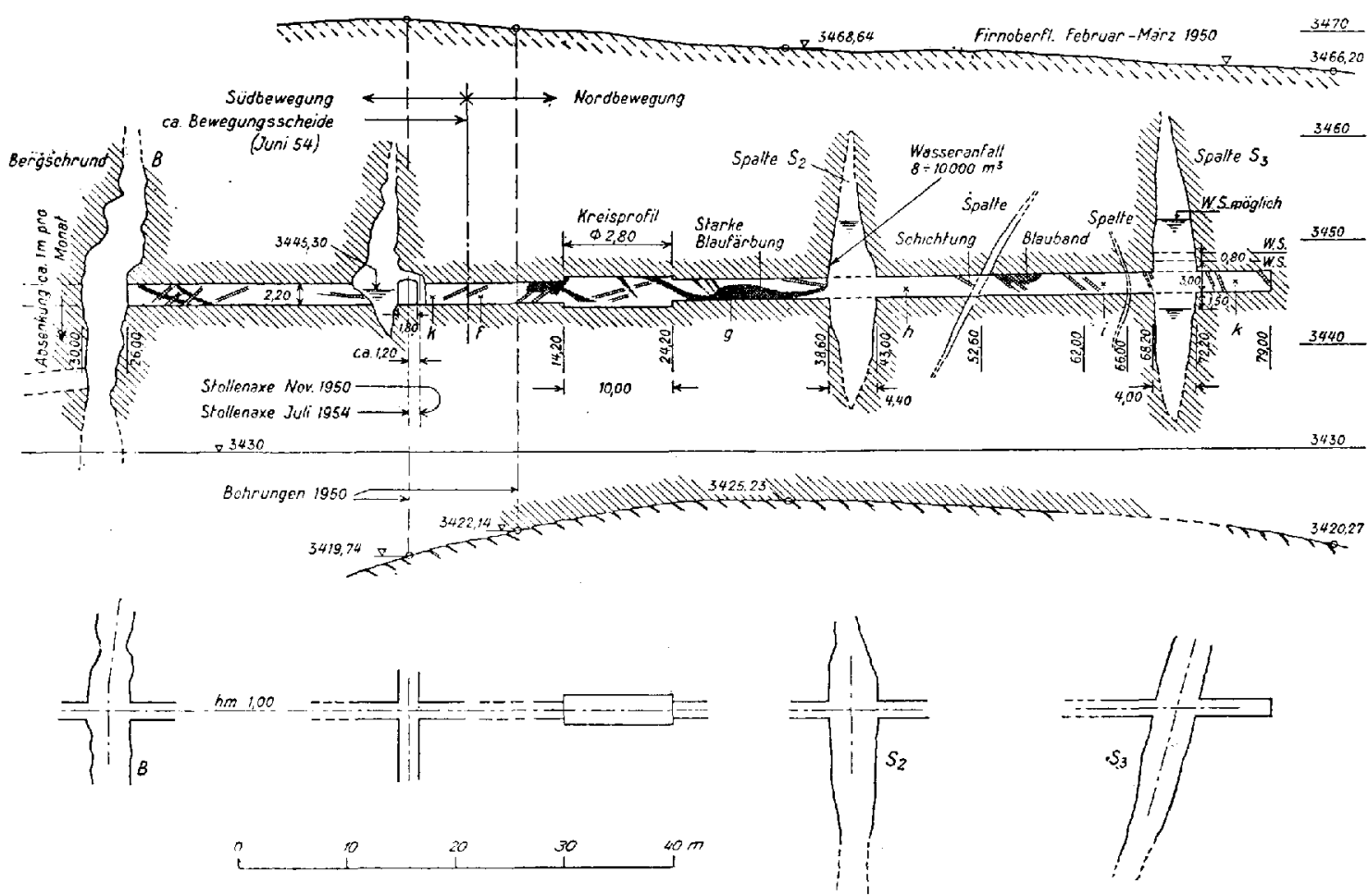

Fig. 7. Cross-tunnel $O_{100 .}$ (above). Section showing firn surface, tunnel with crevasses and blue bands. At the left is the bergschrund $(B)$ beyond which the tunnel sank at the rate of $I \mathrm{~mm}$. per month. (Stollenaxe=longitudinal tunnel axis, Kreisprofil = circular profile, Blaufärbung=blue colouration, Spalte $=$ crevasse, Wasseranfall $=$ water content, Schichtung=layering, Bohrungen=borings.) (below). Plans of various parts. 
a reduction of 20.5 per cent in 687 days, or at a rate of 0.03 per cent per day. For the mean diameter during this period, this corresponds to a reduction of $0 \cdot 0333$ per cent per day. From the type of deformation one can deduce the ratio of the horizontal side pressure to the pressure from above (cf. Sect. V.).

\section{Cross-tunnels (North-South)}

The system of cross-tunnels arranged perpendicularly to the longitudinal tunnel was only extended towards the end of the period of construction, $195^{\circ}-54$, sufficiently for the control of the ice over an adequate number of years. The short side tunnel $Q_{120}$ was completed at the beginning of 1953 , the longer one, $Q_{100}$, which lies in the centre of the cap, being finished in the middle of I954.

In a tunnel running along the division of northerly and southerly movement, only vertical and no horizontal displacements would be experienced. It therefore became a matter of great interest to localize this division of movement within the cap. Amongst other things, the already mentioned cross-tunnels served for this purpose : variations in their length were precisely measured with the aid of dial gauges and measuring tapes.

\section{(a) Cross-tunnel $Q_{120}$}

The rates of horizontal displacement (mm. per day) are given in Fig. 6, as the results of the measurements of length in the cross-tunnel $Q_{120}$ for various lengths of time. These clearly indicate an uninterrupted stretching in the length of this $4 \circ \mathrm{m}$. long tunnel. So as to measure individual sections of the tunnel separately, and to deduce the influence of the cracks, the whole length of tunnel was subdivided into five stretches, and moreover, for the sake of checking, the overall measurement of the whole stretch I-P $\mathrm{P}_{1}$ was taken with the dial gauge at I. Since the continuity of length alterations could be observed directly with the aid of the dial gauges, and since reliable results were obtained over short periods, it was possible, with this system of measurement, to ascertain the position of the division of movement $O$ within a short time. Here, the peg $P_{I}$ in the roof of the main tunnel, whose absolute creep rate $v_{y}$ is known, formed the necessary starting point from which, by aid of the measurement of alterations in length of the cross tunnel $Q_{120}$, it was possible to arrive at absolute horizontal velocities.

Whereas a preliminary measurement $A$ over a short time revealed a pronounced differentiation, i.e. a smaller rate of extension in the middle section of the tunnel than at the ends, the longer measuring time $B$ produced a very even rate of extension of $37 \mathrm{~mm}$. a day. Since the length of the whole measured section was $42 \cdot 25$ metres, ${ }^{*}$ a horizontal rate of strain is arrived at of

$$
\epsilon_{y}=0.0087 \text { per cent per day. }
$$

Surprisingly, all the measurements concurred in showing that the main tunnel is situated in the immediate vicinity of the division of movement, whose position is subject to certain periodic oscillations. The division of movement of the cross-tunnel $\mathrm{Q}_{120}$ may lie somewhat further south than the highest point of the rock base. Since, however, that part of the ice cap lying on the north side of the rock saddle possesses a significantly larger mass than the southern part (cf. Fig. 3), it is easily understood that in these exceptional circumstances part of the ice mass on the southern side of the water shed will be drawn over the higher rock saddle to the north.

The comparison of the stretching in the cross-tunnel with the stretching of the corresponding length on the firn surface is particularly interesting. For this purpose, measuring points were marked with pegs vertically above identical points in the tunnel, and observations were started in I954. From an initial set of such observations taken over a short time, the following comparison can be made, taking, as an example, the cross-tunnel $Q_{120}$ with reference to a measured length of about $40 \mathrm{~m}$. lying in the region of the division of movement:

$$
\begin{aligned}
& \text { Cross-tunnel } Q_{120} \quad \ldots \quad \ldots \quad \ldots \quad 19 / I_{-13} / 4 / 54 \epsilon_{y}=0.0087 \% \text { per day. } \\
& 13 / 4-3 / 8 / 54 \epsilon_{y}=0.0083 \% \text { per day. } \\
& \text { Firn surface } . . \quad \ldots \quad \quad \ldots \quad \ldots \quad 26 / 6-6 / 9 / 54 \epsilon_{0} \cong 0.0178 \% \text { per day. }
\end{aligned}
$$

* The difference in length from that given in Fig. 6 is due to extension which took place in the meantime. 
It should be noted here that probably a substantial part of the measured length-alteration at the surface has taken place in the top-most layer of firn and snow, together with tilting of the measuring rod.

(b) Cross-tunnel $Q_{100}$

This observation gallery, which completes the system of tunnels in the shape of a cross and so, in combination with the longitudinal tunnel and the surface network, permits more complete observation of the ice cap, was only completed in July 1954; there are therefore no measurements available over a sufficient length of time.

The sector of the tunnel lying to the south of the longitudinal tunnel was dug first, on the one hand to establish the exact position of the bergschrund and on the other to provide an exit (window) on to the Jungfrau firn (November I953). Due to the comparatively high vertical speed of the wall of the bergschrund on the valley side, the section of tunnel on the south side of this cleft soon disappeared into the depths and had to be abandoned. During the short period of observation from I2 December I953 to 5 January 1954, the following vertical speeds $v_{z}$ were measured for the points $I-6$ in Fig. 3 :

Table I. Vertical Speeds for Cross-tunnel $Q_{100}$

Points on ice cap, southern section. Measuring period I 2 December I953 to 5 January I954. $y=$ Distance from axis of longitudinal tunnel

\begin{tabular}{|c|c|c|c|c|c|c|c|}
\hline Point & Unit & $\mathbf{I}$ & 2 & 3 & 4 & 5 & 6 \\
\hline$y(+) \mathrm{ca}$. & $\mathrm{m}$. & 6 & $12 \cdot 5$ & 19 & 27 & 33 & 39 \\
\hline$\Delta z$ & & $4^{\circ} 0$ & $3 \cdot 4$ & $3 \cdot 4$ & $62 \cdot 7$ & 29.8 & $42 \cdot 0$ \\
\hline$\Delta v^{z}$ & $\mathrm{~mm} . / \mathrm{day}$ & $1 \cdot 67$ & $1 \cdot 42$ & $I \cdot 42$ & $26 \cdot 0$ & $12 \cdot 0$ & $17 \cdot 6$ \\
\hline$v_{z}^{L}$ & $\mathrm{~mm} \cdot / \mathrm{day}$ & 0.55 & 0.55 & 0.55 & 0.55 & 0.55 & 0.55 \\
\hline$v_{z}$ & $\mathrm{~mm} \cdot / \mathrm{day}$ & $2 \cdot 12$ & $1 \cdot 97$ & $I \cdot 97$ & $26 \cdot 6$ & 12.6 & 18.2 \\
\hline
\end{tabular}

$\Delta v_{z}=$ Difference of velocity with respect to the longitudinal tunnel $v z_{L}=$ Vertical speed of peg in longitudinal tunnel (roof)

$v_{z}=$ Absolute vertical speed of the roof $\left(Q_{100}\right)$.

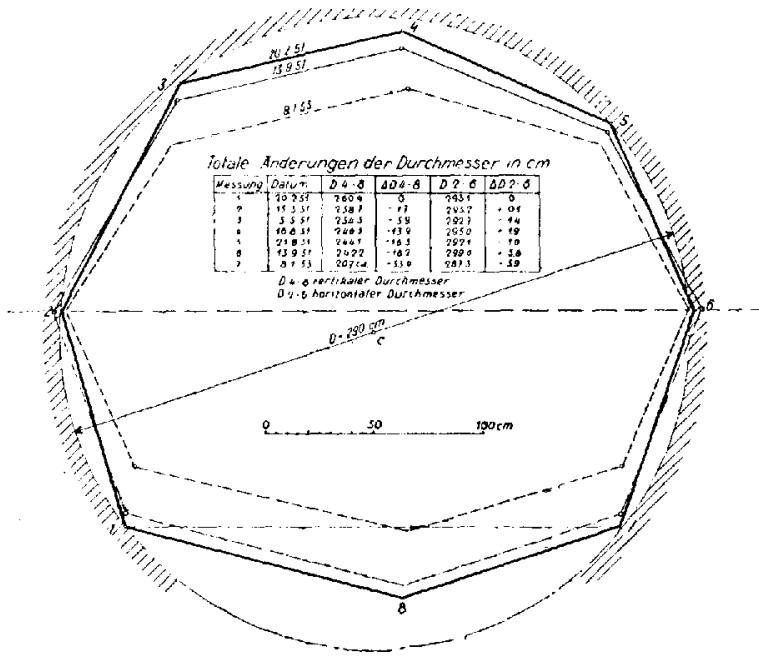

Fig. 8. Circular profile $K_{1}$ in the longitudinal tunnel at hm. I.24-hm. I*3o. Diagram showing change of cross-section from February I95I to Fanuary 1953. The section was below $30 \mathrm{~m}$. of ice, layering was approximately horizontal. $\mathrm{O}=$ measured points. The table shows total variations in diameters in $\mathrm{cm}$. $D_{4}-8$ is vertical diameter, $D_{2}-6$ is horizontal diameter
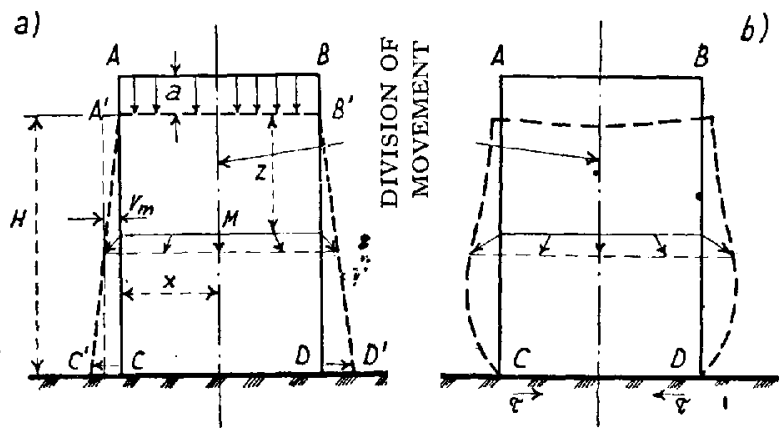

Fig. 9. Diagram to show the relation between accumulation and the profile of motion. In a) with unlimited slipping on the bed, in b) with no slipping 
The fact that the highest vertical speed was observed at Point 4 , can be explained by a rotating movement of the ice masses on the valley side of the bergschrund. The function of the rock base as a slipping surface presupposes the reaching of the point of pressure melting. ${ }^{6}$

(c) Movement relationships and observation of balance in the division of movement

If one imagines a prismatic section, as in Fig. $9 a$ (p. 579), consisting of many horizontal ice layers, independent of one another and free to slip without friction on the base, then the rectangular cross-section would gradually be contorted by the influence of its own weight into the trapezium $\mathrm{A}^{\prime} \mathrm{B}^{\prime} \mathrm{C}^{\prime} \mathrm{D}^{\prime *}$. If section $a$ corresponds to the annual accumulation, then the following equation results, with cross-stretching prevented in planes perpendicular to the section shown:

$$
\begin{aligned}
& a . x=v_{m} . H \\
& a=\frac{v_{m} H}{x}=\epsilon_{m} \cdot H \quad \text {. . . . . . . . . . . }
\end{aligned}
$$

Where:

$a=$ Annual accumulation (height of ice added)

$H=$ Height of the ice block, that is to say depth of the ice cap.

$v_{m}=$ Mean extension of half of the block per year (horizontally in the $x$ direction).

$\epsilon_{m}=$ Mean strain of the block per year (horizontally).

If the ice block consists of a homogeneous column, frozen on to the rock bed, the boundary conditions for the deformation are considerably more complicated (Fig. $9 b$ ), but the above equation remains valid without alteration.

For an average rate of strain $\epsilon_{m}=0.0083$ per cent $\times 36_{5}=3.03$ per cent per year and $H=50 \mathrm{~m}$., an accumulation $a$ of about $\mathrm{I} \cdot 50 \mathrm{~m}$. of ice is necessary to maintain a stationary state. It is further to be realized that, theoretically, there is a possibility of extrusion flow, while in actual fact a series of other influences come into play which confuse the picture and render assessment difficult. The equation (I), formulated as a condition of continuity for the stationary position in the symmetrical axis of an ice cap-can be put into words thus: The uniform deformation of the column of ice at the division of movement takes place in such a way that the product of the mean horizontal strain $\left(\epsilon_{m}\right)$ and the ice depth $H$ remains constant, and equal to the yearly accumulation of ice $a$.

* In must be realized that the sides of $A^{\prime} C^{\prime}$ and $B^{\prime} D^{\prime}$ will in fact become curved inwards as a result of the exponential character of the flow curve (according to Glen ${ }^{7} \dot{E}=k \sigma^{n}$ ), but this does not not affect the argument.

\section{REF E RE N CES}

I. Haefeli, R., and Kasser, P. Geschwindigkeitsverhältnisse und Verformungen in einem Eisstollen des Z'Muttgletschers. U.G.G.I. Association Internationale d'Hydrologie Scientifique. Assemblée Générale de Bruxelles, Tom. I, Part. 3 , I $951, \mathrm{P}, 222-36$

2. Bauer, A. Wissenschaftliche Ergebnisse der französischen Polar-expedition. Naturwissenschaftliche Rundschau, Jahrg. 5, Ht. 1, I952, p. 1-8 and 49-54.

3. Cailleux, A. Premiers enseignements glaciologiques des Expéditions Polaires Françaises 1948-51. Revue de Géomorphologie Dynamique, Tom. 3, No. I, 1952, p. 1-19.

4. Holtzscherer, J.-J., and Bauer, A. Contribution à la connaissance de l'Inlandsis du Groenland. Expéditions Polaires Francaises, Resultats Scientifiques, Nos. N. III. 2 and N. II. 3, I954, 58 p.

5. Perutz, M. F. Direct measurement of the velocity distribution in a vertical profile through a glacier. Fournal of Glaciology, Vol. 1, No. 7, 1950, p. 382-83.

6. Haefeli, R. and Kasser, P. Beobachtungen im Firn- und Ablationsgebiet des Grossen Aletschgletschers. Mitteilungen aus der Versuchsanstalt für Wasserbau und Erdbau, E.T.H. Zürich, No. 15, 1948, 12 pages, also published in Schweizerische Bauzeitung, Bd. 66, Nr. 35/36, 1948, p. $477-8 \mathrm{r}$ and $489-94$.

7. Glen, J. W. Experiments on the deformation of ice. Fournal of Glaciology, Vol. 2, No. 12, 1952, p. I I I-14.

\section{( $T$ o be continued)}




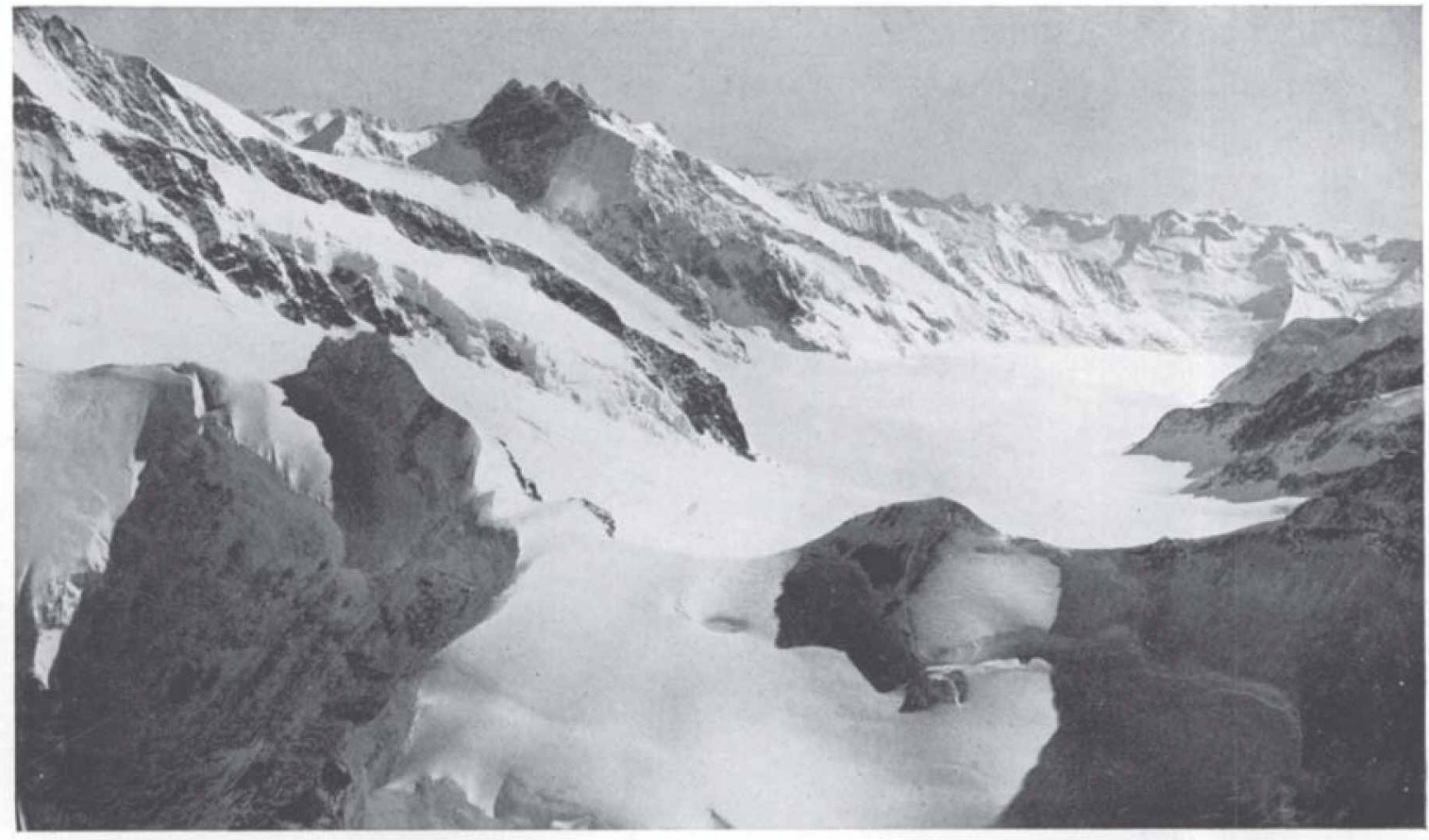

Fig. I. Aerial photograph of the Fungfraujoch Ice Cap from the North Photograph by Suissair-Photo A.G.

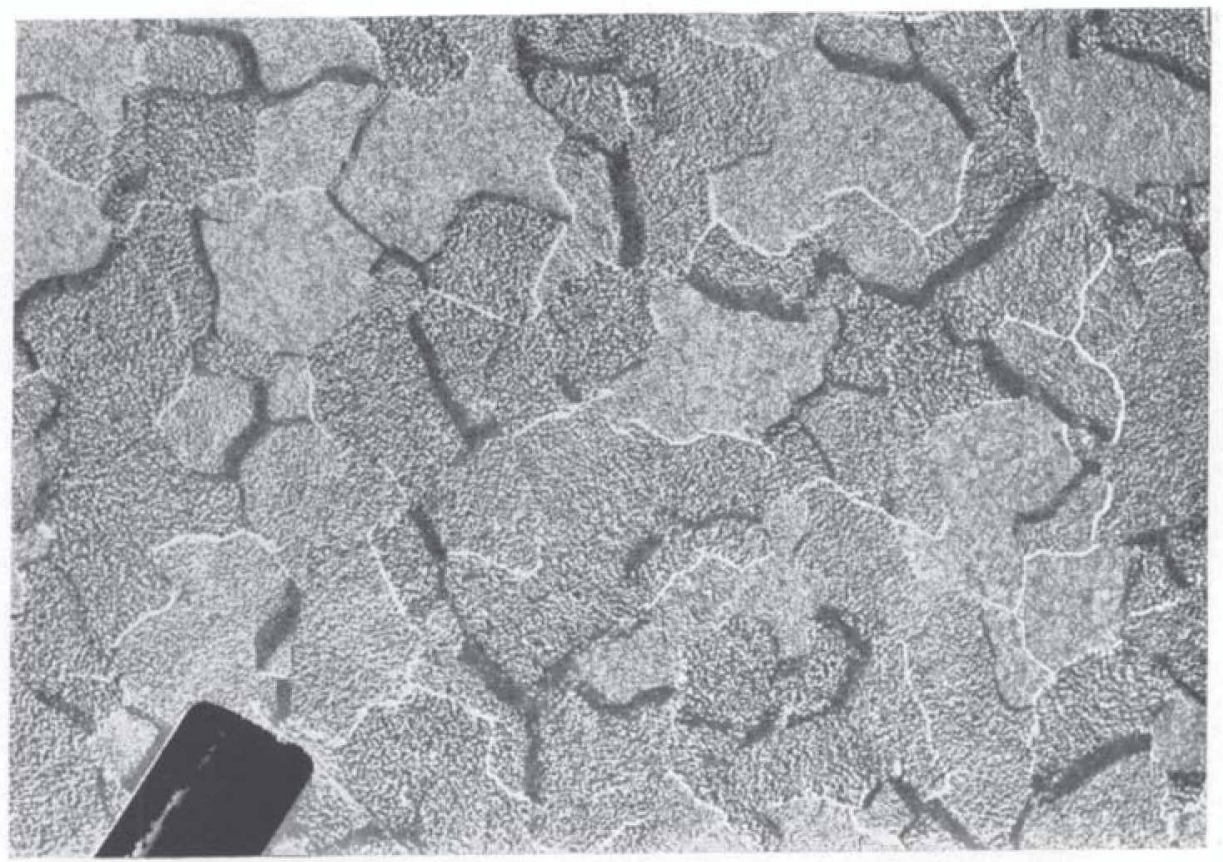

Fig. Io. Surface of a crevasse wall (south wall of crevasse $S_{I}$ at hm. o.7) after depasition of hoar frost (very slightly enlarged). The grain boundaries on the plane ice surface are rendered visible because of the differing orientation and intensity of the deposited hoar, which in turn depends on the crystal axes and the crystallographic nature of the underlying ice. The black lines correspond to a lack of deposit, and the white lines to a maximal deposit, of hoar frost in the boundary region between two crystals 

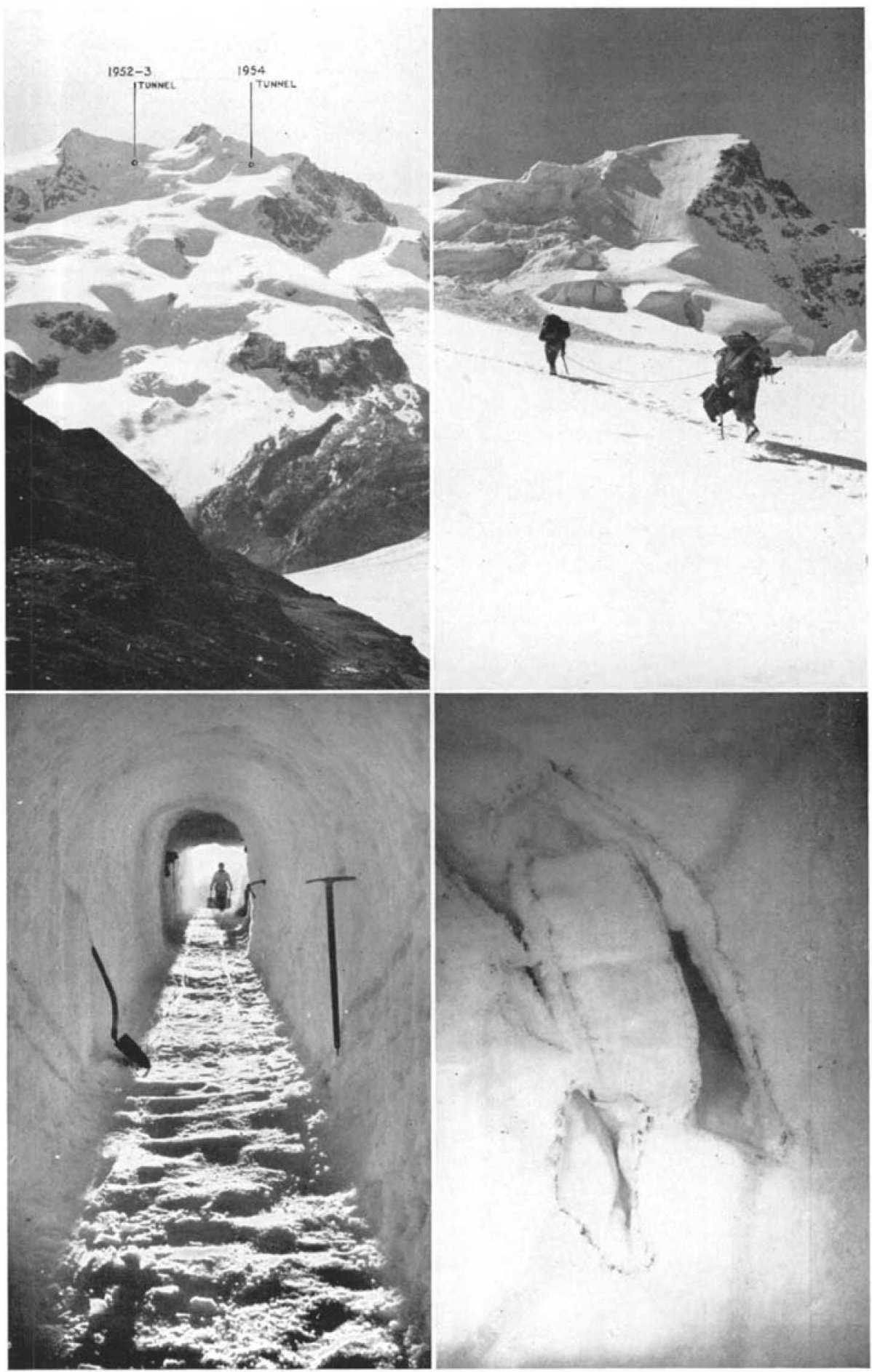

The ice tunnel at the Silbersattel

Above left: Monte Rosa showing the locations of both the 1952-53 tunnel and the 1954 tunnel Above right: On the way to the tunnel

Below left: Tunnel interior, showing dip of strata

Below right: Voids disclosed in névé by tunnel excavation

Photographs by $B$. Wintersteller (Gmunden) 